\title{
1 The impact of fire intensity on plant growth forms in
}

\section{2 high-altitude Andean grassland}

3 Maya A. Zomer ${ }^{1} \&$ Paul M. Ramsay ${ }^{1,2, *}$

$4 \quad{ }^{1}$ School of Biological and Marine Sciences, University of Plymouth, Plymouth, PL4 8AA, UK

5 2Departamento de Ciencias Químico-Biológicas, Universidad de las Américas Puebla, San

6 Andrés Cholula, Puebla, México

$7 \quad$ *Corresponding author: Departamento de Ciencias Químico-Biológicas, Universidad de las

8 Américas Puebla, San Andrés Cholula, Puebla, México; paul.ramsay@udlap.mx

9 ORCID IDs:

10 Maya A. Zomer 0000-0002-3831-7113

11 Paul M. Ramsay 0000-0001-7631-6480 
14 The impact of fire intensity on plant growth forms in 15 high-altitude Andean grassland

\section{Abstract}

Fires in the páramo grasslands of the tropical northern Andes vary in intensity at the landscape scale. Fire suppression strategies, intended to conserve biodiversity and páramo ecosystem integrity and function, could lead to the accumulation of high fuel loads and ultimately fires of higher intensity. Yet the impact of fire intensity on páramos is not well studied or understood. 51/2 years after a fire, we measured plant growth form composition, light transmission to the ground and soil temperature in plots representing very high, high, medium, and low fire intensities, plus a "control" that had been unburned for at least 40 years. We also assessed Espeletia rosette diameters, heights, population density, and mortality. The low intensity plot, with a closed canopy of vegetation and lower growth form diversity, contrasted with the very high intensity plot, with patchy vegetation cover and higher growth form diversity. The high intensity plot had shorter Espeletia plants with smaller rosettes. Light transmission to the ground increased with fire intensity, as did soil temperatures. We demonstrate that the same fire can produce different microenvironmental conditions, plant communities, and population structures in different parts of the same fire event. In future, fire suppression could provoke more intense fires with consequences for ecosystem function and service provision. Since intensity is determined by a complex interaction of factors, we advocate a field programme of experimental fires for a better understanding of páramo fire ecology and to guide effective páramo conservation strategies.

Key words: páramo, Espeletia, soil temperature, light transmission, fire management, burning 


\section{Introduction}

The high-altitude grasslands of the northern Andes, known as páramos, represent the largest extension of tropical alpine ecosystems, extending between the upper treeline and the perennial snowline (about 3200-5000 m altitude) and covering an area of around $35,000 \mathrm{~km}^{2}$ (Madriñán et al. 2013). These biodiverse tropical alpine regions provide important ecological services such as carbon storage and water supply for people and ecosystems at lower elevations. (Buytaert et al. 2011; Ramsay 2014).

Fires have been present in the Andean páramos for thousands of years and are of fundamental significance to the biodiversity patterns and ecological processes of these grasslands (Horn and Kappelle 2009; White 2013). Modern páramo fires are predominantly set by local farmers to encourage new growth for the grazing of livestock. The frequency of burning depends on vegetation recovery but is typically every 2-5 years (Ramsay and Oxley 1996). This has resulted in a mosaic pattern of fire patches at the landscape scale (Laegaard 1992).

Land use in the páramos has shifted in the last two decades, with an intensification of agricultural and recreational use, putting significant pressure on these ecologically important, high diversity systems (Armenteras et al. 2020; Ramsay 2014). As a response, some páramo regions have adopted a fire suppression management strategy to conserve páramo ecosystem integrity and function. A possible unintended consequence of suppression of fires in grassland landscapes is the accumulation of high fuel loads (Keating 2007). Fuel load is the total amount of dry biomass or "the total amount of heat energy available for release during fires" (Whelan 1995). This could potentially lead to less frequent, widespread fires of high intensity that might have significant effects on the landscape (Keating 2007). An understanding of fire intensity and ecosystem response to changes in páramo fire regimes is therefore essential to inform current conservation efforts and management decisions.

The behaviour of páramo fires is highly variable and is determined by factors such as fuel availability, wind direction, site topography, vegetation composition and structure, climatic conditions and human intervention (Horn and Kappelle 2009). Fire intensity refers to energy output during various stages of the fire, including several characteristics such as temperature, residence time, radiant temperature, flame length, and fireline intensity 
(Keeley 2009; Rossi et al. 2018). Fireline intensity is the most commonly used metric of fire intensity and is defined by Byram (1959) as the rate of heat release per unit time per unit length of fire front. Fire severity refers to the post fire loss or change in organic matter above and below ground (Díaz-Delgado et al. 2003; Keeley 2009). Plant mortality is one metric of fire severity, but only if the mortality is the genuine death of the plant rather than temporary loss of material (Keeley 2009). Thus, fire intensity and severity are distinct from one another, but correlated. The most basic understanding of this is that the longer plants are exposed to high temperatures, the more damaging and severe the effects of fire (Ghermandi et al. 2013; Whelan 1995).

Ramsay and Oxley (1996) measured temperatures of a páramo fire and found that temperatures varied depending on the position within the vegetation structure. Maximum temperatures were highest in the upper leaves of tussock grasses (sometimes $>500{ }^{\circ} \mathrm{C}$ ), but were low $\left(<65^{\circ} \mathrm{C}\right)$ amongst the dense leaf bases and just below ground. Thus, plant survival is actually not only dependent on the temperature and duration of fire, but also on the position of a plant's crucial tissues within this tussock structure (Ramsay and Oxley 1996). Post-fire changes in organic matter and post-fire plant community composition therefore reflects fire event conditions combined with the differential survival, recovery and recruitment of plant species (Keeley and Fotheringham 2000). As a result, post-fire ecosystem responses are highly variable in the páramos (Keating 2007; Luteyn 1999; Sklenář and Ramsay 2001; Suárez and Medina 2001). While the roles of fire intensity and severity are widely acknowledged to be important factors in these varying outcomes, the topic is not well studied or understood in páramo ecosystems (Bremer et al. 2019; Horn and Kappelle 2009; Ramsay and Oxley 1996).

The grass páramo of northern Ecuador and Colombia is dominated by tussock grasses and giant rosettes of Espeletia (Asteraceae). Espeletia or 'frailejon' is a flagship plant of the páramos (even represented for several years on the Colombian 100 peso coin) and merits particular attention for this reason. Laegaard (1992) suggested that Espeletia germination and establishment are enhanced after fire opens up the canopy and allows more light to reach the ground. Mature Espeletia plants are resilient to fire because their stems retain dead leaves which provide an insulating layer against lethal fire temperatures, and which are packed so tightly that there is not enough oxygen to sustain burning. The dead leaf cover on Espeletia stems has been reported as a reliable indicator of time since fire in the 
102

103

104

105

106

107

108

109

110

111

112

113

114

115

116

117

118

119

120

121

122

123

124

125

126

127

páramos (Zomer and Ramsay 2018). However, repeated fires, each removing a little more of the dead leaves, expose the stem below. Once the layer of dead leaf bases is destroyed, the plant is thought to be more vulnerable to fire (Laegaard 1992; Smith 1981). Taller (older) plants would normally have been subjected to more fires in their lifetime than shorter plants, and are therefore more susceptible to mortality (Ramsay 2014; Smith 1981).

A rich flora accompanies the dominant tussocks and rosettes, and this diversity makes it difficult to study and interpret community-level successional trends at species level. Many páramo plants have protected buds, rhizomes or rootstock that are able to regenerate after fire even when the rest of the plant has been destroyed, but the mechanisms vary from species to species (Laegaard 1992). Grouping species into functional types that are similar in their resource use and responses to environmental controls (Wilson 1999) has proved useful in other circumstances (Duckworth et al. 2000; Smith and Huston 1989). With broad overview studies in mind, Ramsay and Oxley (1997) proposed ten plant growth forms for the páramos: stem rosettes, basal rosettes, tussock grasses, acaulescent rosettes, cushions and mats, upright shrubs, prostrate shrubs, erect herbs, prostrate herbs and trailing herbs.

Our study takes advantage of observations made by Ramsay (2014) during a single páramo fire event in northern Ecuador, and putative fire intensities of very high, high, medium, and low intensities were assigned to plots all within $600 \mathrm{~m}$ of one another. The fire was extinguished manually and an area at the point where the fire was stopped offered a "control" which had been unburned for at least 40 years. We revisited these same plots $51 / 2$ years after the fire. We aimed to determine the impact of fire intensity on the vegetation and related microclimatic conditions (light availability and temperature). We also considered the impact of fire intensity on the relative abundance of plant growth forms, with particular interest in Espeletia because of its flagship status.

\section{Methods}

\subsection{Study areas}

The Reserva Ecológica El Ángel (REEA), in northern Ecuador, contains approximately 16,000 ha of páramo covering altitudes ranging from $3400 \mathrm{~m}$ to $4200 \mathrm{~m}$. The grass páramos in the reserve are dominated by tussocks of Calamagrostis intermedia (J.Presl) Steud. and giant rosettes of Espeletia pycnophylla Cuatrec. This area has experienced direct impacts 
133 from human activities, including cattle grazing and regular burning of the páramo, as well

134 as conversion of land for cultivation (Moscol Olivera and Cleef 2009). Although the reserve

135 has banned fires since it was established in 1992, fires are still common in certain parts of

136 the buffer zone and adjoining areas within the reserve itself.

137 Ramsay (2014) had the opportunity to observe a single fire that burned through the grass

138 páramo at $3600 \mathrm{~m}$ in the buffer zone of REEA on 3 August 2009. As the fire burned,

139 qualitative observations were made, and putative fire intensities were assigned,

140 representing a relative gradient of very high, high, medium, and low intensities (Ramsay

141 2014). These fire intensity areas burned at approximately the same time (within 2-3

142 hours) and were all located within $600 \mathrm{~m}$ of one another. The fireline was manually

143 extinguished near the high and very high intensity plots, preventing nearby vegetation

144 from burning. Within $10 \mathrm{~m}$ of this fire limit, a plot was established to represent an

145 unburned control. Based on the dead leaf cover of Espeletia plants within this plot (see

146 Zomer and Ramsay 2018), this plot had not been burned for at least 40 years, and was very

147 similar in structure and composition before the fire to the neighbouring high and very high

148 intensity plots. Ramsay (2014) observed the immediate effects of different fire intensities

149 on Espeletia populations and found that the numbers of standing dead plants was clearly

150 correlated with the assigned fire intensities.

\section{$151 \quad 2.2$ Field Measurements and Data Analysis}

152 GPS coordinates were used to locate precisely five areas identified by Ramsay (2014) 51/2

153 years after the August 2009 fire. Representative photographs of these areas, taken during

154 our survey work, are shown in Fig. 1 (which can be compared with the photographs in Fig.

1551 of Garcia-Meneses and Ramsay 2014, showing the plots immediately after the fire).

156 A $50 \mathrm{~m} \times 2 \mathrm{~m}$ plot was established within each area. The plot was divided into one hundred

$1571 \mathrm{~m}^{2}$ quadrats. The presence of ten páramo plant growth forms (Ramsay and Oxley 1997)

158 was recorded for each $1 \mathrm{~m}^{2}$ quadrat. The number of Espeletia giant rosette plants was

159 counted within each plot, along with each plant's height, rosette diameter and whether it

160 was dead or alive. Plants were only included if more than half of the stem, where it entered

161 the ground, was located within the plot. 
162 Vegetation height (excluding Espeletia plants) was measured in each $1 \mathrm{~m}^{2}$ quadrat using

163 the drop-disc method (Stewart et al. 2001), with the resting height of a $20 \mathrm{~cm}$ diameter

164 disc, $190 \mathrm{~g}$ in weight, taken as the vegetation height.

165 Light reaching the ground was determined by comparing measurements of incident

166 photosynthetically active radiation (PAR) using a SunScan Canopy Analysis System with

167 BF2 Beam Fraction Sensor (Delta-T Devices Ltd, Cambridge, UK). The SunScan probe was

168 held at ground level underneath the vegetation at fifty $1 \mathrm{~m}$ intervals along the length of the

169 plot. Each reading consisted of 64 separate light measurements of the percentage of total

170 light above the canopy reaching the sensors on the ground. The mean percentage of total

171 light reaching ground level at each $1 \mathrm{~m}$ interval was calculated, and subsequent analyses

172 were based on these mean values ( $n=50$ for each plot).

173 Soil temperature was measured at $20 \mathrm{~cm}$ soil depth using Signstek 3 1/2 6802 II Dual

174 Channel Digital Thermometer with $2 \mathrm{k}$ Type Thermocouple Sensor Probes. Measurements

175 were taken at five regular intervals along the longest axis of the plot, at $5 \mathrm{~m}, 15 \mathrm{~m}, 25 \mathrm{~m}, 35$

$176 \mathrm{~m}$, and $45 \mathrm{~m}$. At each interval, a temperature reading was taken in three positions of

177 different shading levels: beneath dense tussocks (closed canopy), on the edge of tussocks

178 (intermediate) and in open intertussock areas (open canopy).

179 The Shannon Diversity Index (using $\log _{\mathrm{e}}$ ) and the Gini-Simpson Diversity Index (which

180 particularly emphasizes the role of dominance in diversity) were calculated for growth

181 forms in all plots, using Primer 6 (PRIMER-E, Plymouth, UK). We also used non-metric

182 multidimensional scaling (MDS) in Primer 6 to compare square-root-transformed

183 abundances of growth forms between the fire intensity plots. Other standard statistical

184 tests were performed with R (R Core Team 2019).

\section{Results}

186 Vegetation height (excluding Espeletia) was much taller, and more variable, in the control 187 plot than in the burned ones, while the very high intensity plot had the shortest vegetation 188 (Kruskal-Wallis Test, $X_{4}^{2}=100.21, p<0.0001$; Fig. 2A). The vegetation in the control plot 189 was taller than $2 \mathrm{~m}$ in more than one-quarter of the measurements, while all 190 measurements in the burned plots were less than $1.2 \mathrm{~m}$. More than half the measurements 191 of vegetation height in the very intense fire plot were less than $12.5 \mathrm{~cm}$. 
192

193

194

195

196

197

198

199

200

201

202

203

204

205

206

207

208

209

210

211

212

213

214

215

216

217

218

219

220

221

222

We recorded most light transmission through the canopy to the ground in the very high intensity plot, while the least proportion of available light reached the ground in the low intensity fire plot, with the others intermediate (Kruskal-Wallis Test $X 4^{2}=143.50, p<$ 0.0001; Fig. 2B). The median measure of PAR transmission measurement through the vegetation canopy was $60 \%$ in the very high intensity fire plot, considerably higher than any other plot. While none of the PAR transmission measurements in the very high intensity fire plot fell below $10 \%$, the majority of the measurements in the low intensity fire plot had light transmission at or below that value.

Soil temperature at $20 \mathrm{~cm}$ depth was, on average, $0.4{ }^{\circ} \mathrm{C}$ higher in places with an open canopy compared with places with a closed canopy, while intermediate canopy cover were not significantly different from open or closed canopies (GLM ANOVA, Canopy $F_{2,60}=4.641$, $p<0.0134$; Fig.5C). Soil temperatures were highest in the very high intensity fire plot, with the medium intensity, low intensity and unburned control plots similarly low, while the high intensity plot was intermediate (GLM ANOVA, Intensity $F_{4,60}=38.069, p<0.0001$; Fig. 2C). The difference in temperature between these two groups was approximately $1.75^{\circ} \mathrm{C}$. There was no interaction of soil temperature between fire intensity and vegetation canopy cover (GLM ANOVA, Intensity x Canopy $F_{8,60}=0.036, p=0.9949$ ).

Plant growth form composition differed among the fire intensity plots (Table 1). Tussocks were almost ubiquitous in all but the very high intensity and unburned control plots, where they were nevertheless very abundant. Giant stem rosettes were also very abundant in all plots. Upright shrubs, cushions and mats, prostrate herbs, and giant basal rosettes were most abundant in the very high intensity plot, and least abundant in the low intensity plot.

Erect herbs and prostrate shrubs showed a similar pattern, though their highest abundances were in the medium intensity plots. Acaulescent rosettes were found in low abundance in all burned plots, and were absent from the unburned control, while trailing herbs were absent from all burned plots, and were only found, in low abundance, in the unburned control. Diversity of plant growth forms in the plots was lowest in the low intensity burned plot but was similar among the others (Table 1).

In terms of overall growth form composition, the plots were 69-90\% similar but the low intensity plot was the most distinct from the others, particularly the very high fire intensity plot (Fig. 3). However, there was no clear trend with respect to the fire intensity gradient. 
223 Espeletia plants which survived the very high intensity fire plot had smaller rosettes and

224 were shorter than in the other plots, though there was no clear trend associated with fire

225 intensity in the rest of the plots (GLM ANOVA for plant height, $F_{4,147}=20.42, p<0.0001$;

226 Kruskal-Wallis Test for rosette diameter, $X_{4}^{2}=49.16, p<0.0001$; Fig 4).

227 The number of plants which had survived the fire (plants $>0.5 \mathrm{~m}$ tall at the time of survey)

228 did not show a clear relationship with fire intensity (Fig. 5, white), but there was a clear

229 mortality effect in the very high intensity plot compared with the low intensity plot, with

230 the other plots intermediate (Fig. 5, black). Recruitment of Espeletia plants after the fire

231 was lowest in the very high and low intensity plots, and higher in the plots of intermediate

232 fire intensity (Fig. 5, grey). The unburned control plot had a similar number of new recruits

233 to those found in the highest-recruiting burned plots.

\section{Discussion}

235 The impact of fire intensity on páramo vegetation was still evident $5 \frac{1}{2} 2$ years after the fire:

236 clear differences between very high and low intensity plots in terms of micro-

237 environmental measurements, which were reflected in the growth form composition of the

238 vegetation and in Espeletia population structure.

239 Tussocks showed little variation in response to fire intensities except at the very high

240 intensity, where their abundance was much lower. Tussock grasses are typically the most

241 competitive growth form in páramo plant communities and are usually able to re-sprout

242 after fire (Ramsay and Oxley 1996). It seems that only very high intensity fires generate

243 lethal temperatures in the tussock bases, killing parts or whole tussocks, and thereby

244 stunting tussock grass recovery (Ramsay and Oxley 1996). This is consistent with findings

245 by Ghermandi et al. (2013) that showed high severity fires reduced the perennial herb and

246 perennial grass and shrub cover in Patagonian steppe grasslands due to the mortality of

247 entire or partial bud banks of these re-sprouter species.

248 Espeletia maintained relatively high abundances in all fire intensities but was most

249 abundant in the intermediate intensities that allowed for the survival of Espeletia adult

250 plants, while still providing adequate space and light for successful establishment of a post-

251 fire germination pulse. Verweij and Kok (1992) also reported Espeletia higher recruitment

252 after fire in a Colombian páramo. Lower intensity sites had lower juvenile recruitment,

253 since these fires move faster and leave some patches unburned (Ramsay 2014), and thus 
254 remove less of the tussock canopy. The greatest abundance of juveniles, however, was

255 found in the intermediate rather than very high intensities. This suggests that while fire is

256 an important disturbance factor to create germination space, there is a threshold of fire

257 intensity after which recruitment is no longer enhanced. This might be explained by heat

258 penetration into the soil and consequent seed mortality (Bond and van Wilgen 1996;

259 Fidelis et al. 2010; Horn 1997).

260 Very high intensity fire also resulted in shorter plants and smaller rosettes of Espeletia.

261 Higher mortality rates of taller Espeletia plants immediately after the fire in this plot

262 (Ramsay 2014) explains the shorter population 5 $\frac{1}{2} 2$ years later. The mortality of these older

263 plants is likely associated with the gradual loss of dead leaves that protect the stem, either

264 by decades of decomposition nearer the base or by gradual removal in previous fires. In a

265 high intensity fire, younger plants with thicker dead leaf cover are more likely to survive

266 (Laegaard 1992; Ramsay 2014; Smith 1981). Very high intensity fires might stunt the

267 growth of rosettes by causing long-term damage to the meristem or modifying

268 environmental conditions that affects the rosettes growth. In the absence of fire, Espeletia

269 plants occasionally show pronounced temporary reductions in rosette diameter, with later

270 recovery, perhaps in response to disease or predator attack (personal observations of the

271 authors). Small-diameter rosettes in adult plants are, therefore, potential signals of plants

272 under stress.

273 Upright shrubs, giant basal rosettes, cushion/mats, prostrate shrubs, prostrate herbs, and 274 erect herbs all increased in frequency as fire intensity increased. These growth forms take

275 advantage of reduced competition from tussocks, the higher availability of light, and

276 warmer soils. Some upright shrubs re-sprout well after fire, from insulated buds or roots,

277 and are known to thrive in fire prone environments (Horn and Kappelle 2009; Ramsay and

278 Oxley 1996). The frequency of shrubs in our survey was measured by rooted presence, thus

279 our result showed an increase in plant number, rather than increasing canopy size. It is

280 likely that it was driven by a combination of re-sprouting from root systems (with

281 relatively rapid growth) and new recruitment from seed, despite the rapid return of

282 tussock canopy cover after fires (Gutiérrez-Salazar and Ramsay in press).

283 Adults of Puya hamata giant basal rosettes are known to survive fire very well, even in high 284 intensity fires (Laegaard 1992). Garcia-Meneses and Ramsay (2014) surveyed Puya hamata 285 survival rates immediately after the fire in the same plots we visited, and found only $4.3 \%$ 
of rosettes died (all of them were small plants) in the very high intensity plot. García-

Meneses (2012) demonstrated that Puya hamata seeds only germinated when soil temperatures exceeded $13^{\circ} \mathrm{C}$ (around $3^{\circ} \mathrm{C}$ above ambient daytime air temperatures in our study plots), so the higher light and warmer soil temperatures after higher intensity fires would be expected to promote germination. In the same way, it is likely that cushion/mats, prostrate shrubs, prostrate herbs, and erect herbs suffered increased mortality with greater fire intensities, but this was outweighed by higher rates of subsequent recruitment due to the more open tussock canopies after higher intensity fires.

294 Acaulescent rosettes were present in relatively low numbers in the burned plots, and 295 completely absent from the unburned control. It is expected that this growth form is more 296 light demanding, and favours the canopy gaps created by burning (Zomer and Ramsay in 297 review). Trailing herbs were only present in the unburned control and absent from all 298 burned plots. Since they often depend on intact tussock grass canopies to climb, it is 299 possible they need more time to establish than $5 \frac{1}{2} 2$ years after fire, but it is also possible 300 that seed dispersal in our study area was low.

301 It is important to note that our study did not look at detailed composition of plant species. 302 Our growth form approach does not reveal if there is a turnover of species within each 303 growth form between intensities. It is therefore very likely that compositional differences 304 between fire intensity plots would be more pronounced (but also noisier) at the species 305 level.

306 The unburned plot had the most heterogeneous vegetation structure, light at ground level 307 was relatively high, and upright shrubs were observed to be the dominant growth form rather than tussocks. The populations of Espeletia in the unburned area were similar in density to those found in some of the burned plots, with many tall Espeletia as well as an abundance of Espeletia seedlings. This suggests that without fire disturbance upright

311 shrubs can become codominant with tussocks, reducing the canopy cover of the tussocks, 312 and allowing enough light to filter through for Espeletia germination and growth. This is a 313 very interesting result, as it has been previously assumed that Espeletia would not thrive 314 without fire (Laegaard 1992), and raises some interesting questions about the successional 315 trajectory of paramo plant communities (see Zomer and Ramsay in review).

316 Our assessment of páramo fire intensity has demonstrated that the same fire can produce different environmental conditions, plant communities, and population structures in 
different parts of the same fire event. Real fires consist of a patchwork of different fire intensities, the extremes of which produce very different ecological outcomes from intermediate intensities. Clearly, fire management policies for páramo grasslands should consider fire intensity as well as fire frequency (Armenteras et al. 2020; Bremer et al. 2019). A major obstacle to taking fire intensity into account is that it is difficult to measure.

323 Fire intensity is usually measured during the fire event itself. In a study of African savannas, Govender et al. (2006) estimated fire intensity from measurements of fuel loads, fuel moisture contents, rates of fire spread and heat yields of fuel in experimental plots. However, direct measurement of intensity in the páramo will not be possible in most cases, given the remoteness, difficult terrain, cloudy skies (blocking the use of satellite imagery) and lack of investment in research.

Various surrogate indicators have been used in some grasslands as post-fire measures of fire intensity and severity, including leaf and bark scorch height, skeleton twig diameter, ash deposition and plant mortality (Ghermandi et al. 2013; Govender et al. 2006). In the páramo, Espeletia plants can act as reliable indicators of time since fire (Zomer and Ramsay 2018), but our current study has demonstrated that Espeletia size and population structure did not act as a reliable indicator of fire intensity, except for very high fire intensity. Light transmission to ground level did show a consistent pattern along the full scale of burned intensity plots (very high, high, medium, low). Light decreased as fire intensity decreased.

337 A promising direction would therefore be to focus on light transmission to ground level as an indicator of post-fire intensity. However, there may be a time limit after which these signals can no longer be picked up. It would be useful to follow up this study by continuing to monitor the fire intensity sites assessed in this study to see how long these patterns

341 persist after fire. A complicating factor is that grazing by livestock follows burning in many 342 páramos, and has been shown to further open up vegetation canopies and reduce Espeletia densities (Verweij and Kok 1992; Zomer and Ramsay in review).

344 Despite the difficulties in determining fire intensity, changes in climate and land use are 345 likely to increase the intensity of páramo fires (Armenteras et al. 2020; Keating 2007). Fire 346 suppression policies could result in high fuel loads and greater fire intensities when fires 347 do happen, promoted by more extreme weather events and higher numbers of tourists in 348 the mountains. Our study has shown this could change vegetation composition and the balance of some microenvironmental conditions. Greater proportions of páramo with 
reduced tussock cover, more bare ground, and higher soil temperatures could have consequences for ecosystem function. High vegetation cover of tussock grasses is often associated with protecting páramo soils that provide water regulation and store and sequester soil carbon (Bremer et al. 2019; Minaya Maldonado 2017). Molina et al. (2019) have linked tussock cover to chemical weathering of páramo soils. More consideration needs to be focused on the impacts of fire suppression policies in the longer term on fire intensities, and the impacts of fire intensities on ecosystem function and service provision.

Our study was provoked by good fortune-being present during a páramo fire with a wide range of fire intensities-but such luck cannot form the basis for a research programme that is badly needed to inform páramo management. Instead, we require a field programme of experimental fires, covering a wide range of fuel loads and land uses. As an illustration of the value of this approach, we refer readers to work carried out in Australian grasslands (Cruz et al. 2018). Very few experimental burns have been carried out in the páramos so far (Horn and Kappelle 2009; Keating 1998; Ramsay and Oxley 1996), but a well-designed experimental programme could form the basis for detailed modelling of fire behaviour and also provide years of subsequent value for monitoring the responses of biodiversity and ecosystem functions to those fires.

\section{Acknowledgements}

368 This work was carried out as part of permit MAE-DPAC-UPN-BD-IC-FLO-2015-004, issued 369 by the Ecuadorian Ministry of Environment (Carchi province). Fieldwork was carried out 370 by the authors, with assistance from Anna Masters, Cheryl McAndrew, Patricia Gutierrez 371 Salazar, Alejandro Marchán \& Juan Yépez Cardenas. Logistical support in REEA was 372 provided by the reserve's administration and rangers, who also provided information from 373 fire records.

\section{References}

Armenteras D, González TM, Vargas JO, Meza Elizalde MC, Oliveras I (2020) Incendios en ecosistemas del norte de Suramérica: avances en la ecología del fuego tropical en Colombia, Ecuador y Perú. Caldasia 42:16 doi:10.15446/caldasia.v42n1.77353 
bioRxiv preprint doi: https://doi.org/10.1101/2020.04.25.061051; this version posted April 27, 2020. The copyright holder for this preprint (which was not certified by peer review) is the author/funder, who has granted bioRxiv a license to display the preprint in perpetuity. It is made available under aCC-BY-NC-ND 4.0 International license.

381

382

383

384

385

386

387

388

389

390

391

392

393

394

395

396

397

398

399

400

401

402

403

404

405

406

407

408

409

410

411

412

413

414

415

416

417

418

419

420

421

422

lessons from páramo grasslands. Biodiversity and Conservation 28:885-908 doi:10.1007/s10531-019-01700-3

Buytaert W, Cuesta-Camacho F, Tobón C (2011) Potential impacts of climate change on the environmental services of humid tropical alpine regions. Global Ecology and Biogeography 20:19-33 doi:10.1111/j.1466-8238.2010.00585.x

Byram GM (1959) Combustion of forest fuel. In: Davis KP (ed) Forest Fire: Control and Use. 2 edn. McGraw-Hill, New York,

Cruz MG, Sullivan AL, Gould JS, Hurley RJ, Plucinski MP (2018) Got to burn to learn: the effect of fuel load on grassland fire behaviour and its management implications. International Journal of Wildland Fire 27:727-741 doi:https://doi.org/10.1071/WF18082

Díaz-Delgado R, Lloret F, Pons X (2003) Influence of fire severity on plant regeneration by means of remote sensing imagery. International Journal of Remote Sensing 24:17511763 doi:10.1080/01431160210144732

Duckworth JC, Kent M, Ramsay PM (2000) Plant functional types: an alternative to taxonomic plant community description in biogeography? Progress in Physical Geography: Earth and Environment 24:515-542 doi:10.1177/030913330002400403

Fidelis A, Delgado-Cartay MD, Blanco CC, Müller SC, Pillar VD, Pfadenhauer J (2010) Fire intensity and severity in Brazilian campos grasslands. Interciencia 35:739-745

García-Meneses PM (2012) Landscape-scale population dynamics: field observations and modelling of Puya hamata, a flagship plant from the Andes. Plymouth University

Garcia-Meneses PM, Ramsay PM (2014) Puya hamata demography as an indicator of recent fire history in the páramo of El Ángel and Volcán Chiles, Ecuador-Colombia. Caldasia 36:53-69

Ghermandi L, Gonzalez S, Lescano MN, Oddi F (2013) Effects of fire severity on early recovery of Patagonian steppes. International Journal of Wildland Fire 22:10551062 doi:10.1071/WF12198

Govender N, Trollope WSW, Van Wilgen BW (2006) The effect of fire season, fire frequency, rainfall and management on fire intensity in savanna vegetation in South Africa. Journal of Applied Ecology 43:748-758 doi:10.1111/j.1365-2664.2006.01184.x

Gutiérrez-Salazar PM, Ramsay PM (in press) Physiognomic responses of páramo tussock grass to time since fire in northern Ecuador. Revista Peruana de Biología

Horn SP (1997) Postfire resprouting of Hypericum irazuense in the Costa Rican páramos: Cerro Asunción revisited. Biotropica 29:529-531

Horn SP, Kappelle M (2009) Fire in the páramo ecosystems of Central and South America. In: Cochrane MA (ed) Tropical Fire Ecology: climate change, land use, and ecosystem dynamics. Praxis, Chichester, UK, pp 505-539

Keating PL (1998) Effects of anthropogenic disturbances on Paramo vegetation in Podocarpus National Park, Ecuador. Physical Geography 19:221-238

Keating PL (2007) Fire ecology and conservation in the high tropical Andes: observations from northern Ecuador. Journal of Latin American Geography 6:43 
bioRxiv preprint doi: https://doi.org/10.1101/2020.04.25.061051; this version posted April 27, 2020. The copyright holder for this preprint (which was not certified by peer review) is the author/funder, who has granted bioRxiv a license to display the preprint in perpetuity. It is made available under aCC-BY-NC-ND 4.0 International license.

Keeley JE (2009) Fire intensity, fire severity and burn severity: a brief review and suggested usage. International Journal of Wildland Fire 18:116-126 doi:10.1071/wf07049

Keeley JE, Fotheringham C (2000) Role of fire in regeneration from seed. In: Fenner M (ed) Seeds: the Eology of Rgeneration in Pant Cmmunities. 2 edn. CABI, Wallingford, UK, pp 311-330

Laegaard S (1992) Influence of fire in the grass páramo vegetation of Ecuador. In: Balslev H, Luteyn JL (eds) Páramo: An Andean Ecosystem under Human Influence. Academic Press, London, pp 151-170

Luteyn JL (1999) Páramos: a checklist of plant diversity, geographical distribution and botanical literature. The New York Botanic Garden, New York

Madriñán S, Cortés AJ, Richardson JE (2013) Páramo is the world's fastest evolving and coolest biodiversity hotspot. Frontiers in Genetics 4 doi:10.3389/fgene.2013.00192

Minaya Maldonado VG (2017) Ecohydrology of the Andes Páramo Region. Delft University of Technology and UNESCO-IHE Institute for Water Education

Molina A, Vanacker V, Corre MD, Veldkamp E (2019) Patterns in soil chemical weathering related to topographic gradients and vegetation structure in a High Andean tropical ecosystem. Journal of Geophysical Research: Earth Surface 124:666-685 doi:10.1029/2018jf004856

Moscol Olivera MC, Cleef AM (2009) A phytosociological study of the paramo along two altitudinal transects in El Carchi province, northern Ecuador. Phytocoenologia 39:79-107 doi:10.1127/0340-269x/2009/0039-0079

R Core Team (2019) R: A language and environment for statistical computing. $\mathrm{R}$ Foundation for Statistical Computing, Vienna

Ramsay PM (2014) Giant rosette plant morphology as an indicator of recent fire history in Andean paramo grasslands. Ecol Indic 45:37-44 doi:10.1016/j.ecolind.2014.03.003

Ramsay PM, Oxley ERB (1996) Fire temperatures and postfire plant community dynamics in Ecuadorian grass paramo. Vegetatio 124:129-144

Ramsay PM, Oxley ERB (1997) The growth form composition of plant communities in the Ecuadorian paramos. Plant Ecology 131:173-192

Rossi JL, Chatelon FJ, Marcelli T (2018) Fire Intensity. In: Manzello SL (ed) Encyclopedia of Wildfires and Wildland-Urban Interface (WUI) Fires. Springer International Publishing, Cham, pp 1-6. doi:10.1007/978-3-319-51727-8_51-1

Sklenář P, Ramsay PM (2001) Diversity of zonal páramo plant communities in Ecuador. Diversity and Distributions 7:113-124

Smith AP (1981) Growth and population dynamics of Espeletia (Compositae) in the Venezuelan Andes. Smithsonian Contributions to Botany 48:1-45

Smith TM, Huston MA (1989) A theory of the spatial and temporal dynamics of plant communities. Vegetatio 83:49-69

Stewart KEJ, Bourn NAD, Thomas JA (2001) An evaluation of three quick methods commonly used to assess sward height in ecology. Journal of Applied Ecology 38:1148-1154 doi:10.1046/j.1365-2664.2001.00658.x 
bioRxiv preprint do: https://doi.org/10.1101/2020.04 25.061051; this version posted April 27, 2020. The copyright holder for this preprint (which was not certified by peer review) is the author/funder, who has granted bioRxiv a license to display the preprint in perpetuity. It is made available under aCC-BY-NC-ND 4.0 International license.

465

466

467

468

469

470

471

472

473

474

475

476

477

478

479

480

481
Suárez E, Medina G (2001) Vegetation structure and soil properties in Ecuadorian paramo grasslands with different histories of burning and grazing. Arctic, Antarctic, and Alpine Research 33:158-164

Verweij PA, Kok K (1992) Effects of fire and grazing on Espeletia hartwegiana populations. In: Balslev H, Luteyn JL (eds) Páramo: An Andean Ecosystem under Human Influence. London, Academic Press, pp 215-229

Whelan RJ (1995) The Ecology of Fire. Cambridge University Press, Cambridge

White S (2013) Grass paramo as hunter-gatherer landscape. Holocene 23:898-915 doi:10.1177/0959683612471987

Wilson JB (1999) Guilds, functional types and ecological groups. Oikos 86:507-522

Zomer MA, Ramsay PM (2018) Espeletia giant rosette plants are reliable biological indicators of time since fire in Andean grasslands. Plant Ecology 219:79-88 doi:10.1007/s11258-017-0779-X

Zomer MA, Ramsay PM (in review) Post-fire changes in plant growth form composition in Andean páramo grassland. Applied Vegetation Science 
bioRxiv preprint do: https://doi org/101101/2020 04 25.061051: this version posted April 27, 2020. The copyright holder for this preprint (which was not certified by peer review) is the author/funder, who has granted bioRxiv a license to display the preprint in perpetuity. It is made available under aCC-BY-NC-ND 4.0 International license.

\section{Tables}

483 Table 1. Abundance and diversity of growth forms in plots of different fire intensities, $5 \frac{1}{2}$ years

484 after the fire. Abundance is shown as frequency in $1001-\mathrm{m}^{2}$ subdivisions of each plot.

\section{Growth Forms}

Tussocks

Upright Shrubs

Cushion/Mat

Prostrate Herbs

Erect Herbs

Giant Basal Rosette

Giant Stem Rosette

Prostrate Shrubs

Acaulescent Rosette

Trailing Herbs

Shannon Diversity

Simpson-Gini Diversity

Fire Intensity

Control

\begin{tabular}{ccccc}
\cline { 1 - 3 } Very High & High & Medium & Low & \\
\cline { 1 - 3 } 75 & 99 & 100 & 100 & 79 \\
76 & 15 & 20 & 10 & 73 \\
87 & 12 & 39 & 5 & 2 \\
81 & 40 & 34 & 12 & 51 \\
16 & 9 & 26 & 5 & 21 \\
51 & 26 & 32 & 8 & 42 \\
74 & 74 & 82 & 61 & 91 \\
33 & 29 & 44 & 6 & 34 \\
1 & 1 & 7 & 3 & 0 \\
0 & 0 & 0 & 0 & 2 \\
\hline 2.00 & 1.81 & 1.99 & 1.49 & 1.90 \\
0.86 & 0.80 & 0.84 & 0.68 & 0.84 \\
\hline
\end{tabular}

485 


\section{Figure Captions}

488 Fig. 1. Plots of different fire intensity in April 2015, 51/2 years after the August 2009 fire.

489 Photos: Maya Zomer.

490 Fig. 2. (A) Vegetation height (excluding Espeletia, $n=100$ in each case), (B) light reaching

491 the ground ( $n=50$ in each case), and (C) soil temperatures at $20 \mathrm{~cm}$ depth $(n=15$ in each

492 case) in plots of different fire intensities, 51/2 years after the fire. Medians are shown as central

493 lines, except in (C) which shows means, boxes are $25^{-7} 5^{\text {th }}$ percentiles, whiskers are $10-90^{\text {th }}$

494 percentiles, and the dots show 5-95 th percentiles. Medians/means sharing a letter in each

495 panel were not significantly different $(p \leq 0.05)$.

496 Fig. 3. Similarity in plant growth form composition of plots of different fire intensities, 51/2

497 years after the fire. Compositional similarity is represented as distance using non-metric

498 multidimensional scaling: points closer together are more similar in composition. Stress

499 was $<0.01$.

500 Fig. 4. Rosette diameter (A) and height (B) of surviving Espeletia plants in plots of different

501 fire intensities, $5 \frac{1}{2} 2$ years after the fire. The control plot had not been burned for at least 40

502 y. Only plants $>50 \mathrm{~cm}$ tall at the time of survey were included, since shorter plants were

503 assumed to have arrived after the fire event. Representations of percentiles are as described

504 for Fig. 2. Medians sharing a letter in each panel were not significantly different $(p \leq 0.05)$.

505 Fig. 5. Number of Espeletia plants $\mathrm{m}^{-2}$ in plots of different fire intensities, $5 \frac{1}{2} 2$ years after

506 the fire. White = plants assumed to have been present during the last fire (plants $>50 \mathrm{~cm}$

507 tall at the time of survey); grey = plants assumed to have colonised after the last fire; black $508=$ standing dead plants. 
bioRxiv preprint doi: https://doi org/10.1101/2020.04 25.061051 this version posted April 27, 2020. The copyright holder for this preprint (which was not certified by peer review) is the author/funder, who has granted bioRxiv a license to display the preprint in perpetuity. It is made available under aCC-BY-NC-ND 4.0 International license.

Fig. 1

Very High

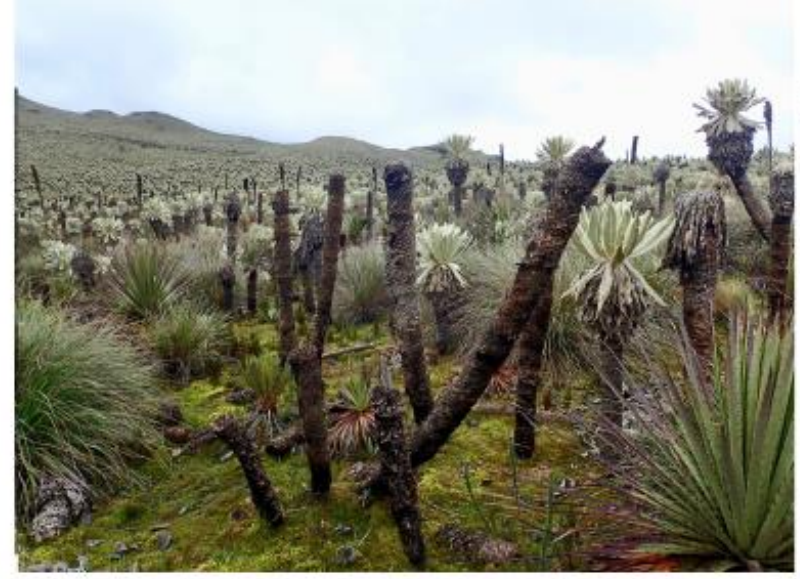

Medium

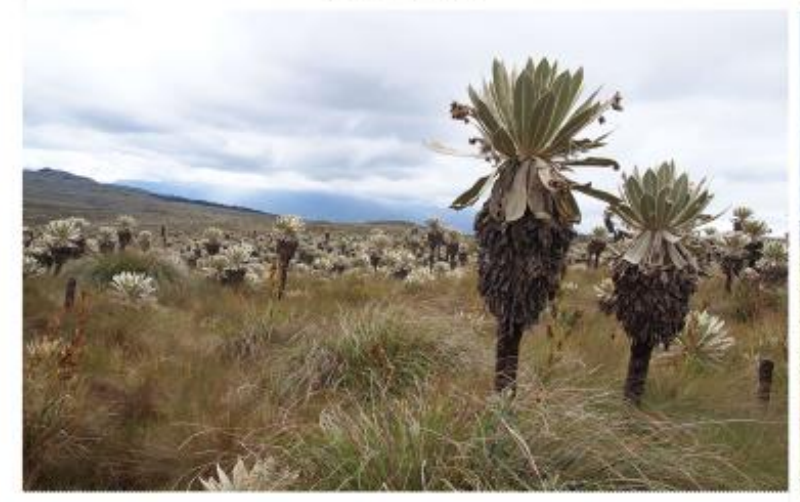

Recently Unburned Control

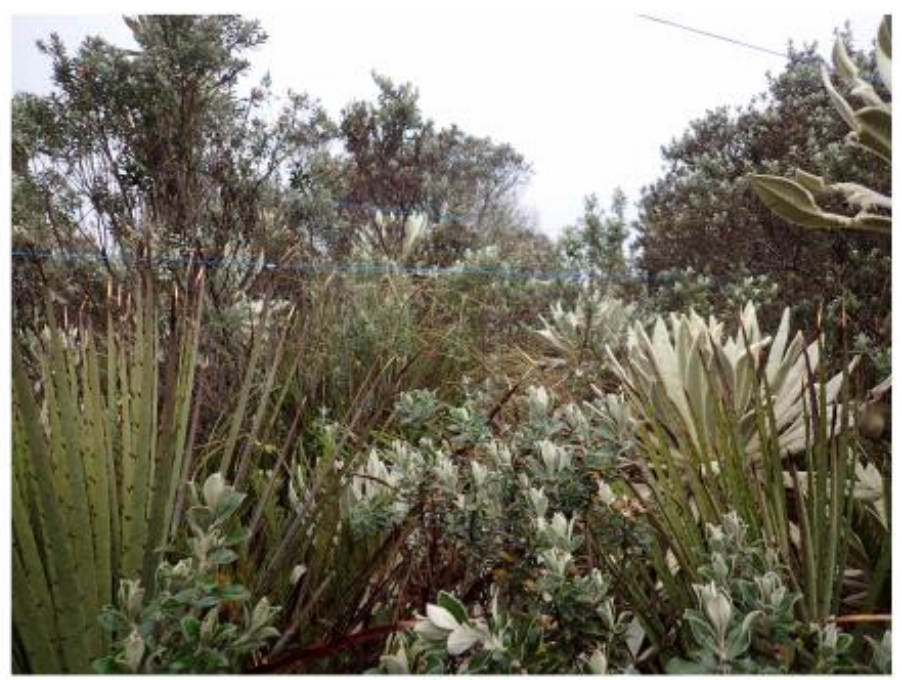

High

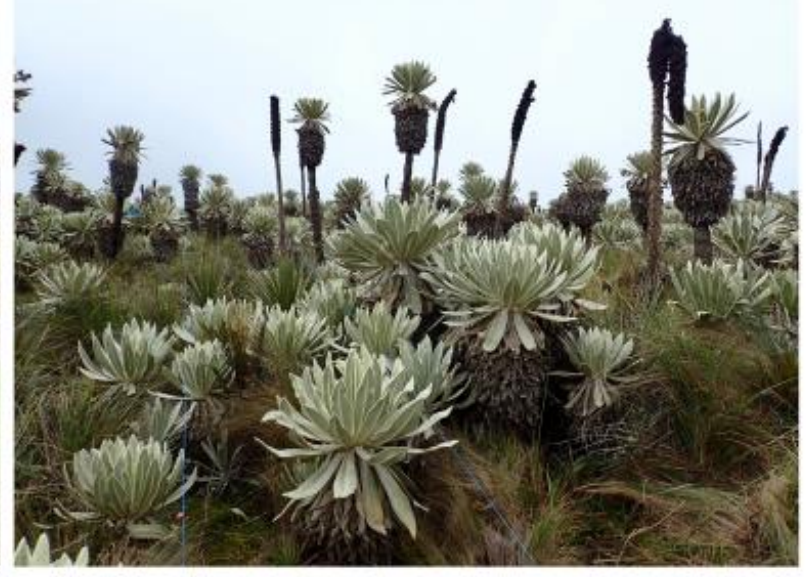

Low
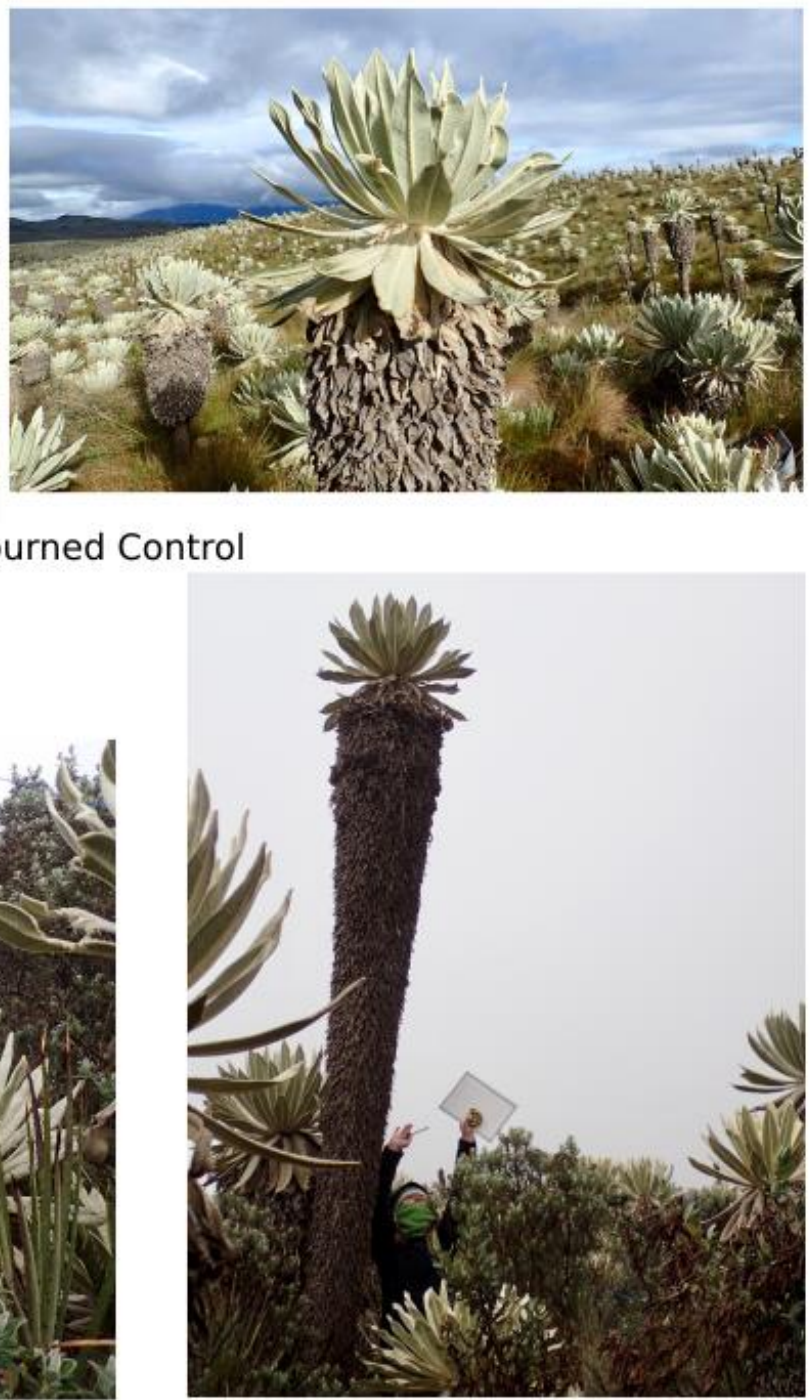
bioRxiv preprint doi: https://doi.org/10.1101/2020.04.25.061051; this version posted April 27, 2020. The copyright holder for this preprint (which was not certified by peer review) is the author/funder, who has granted bioRxiv a license to display the preprint in perpetuity. It is made available under aCC-BY-NC-ND 4.0 International license.

Fig. 2
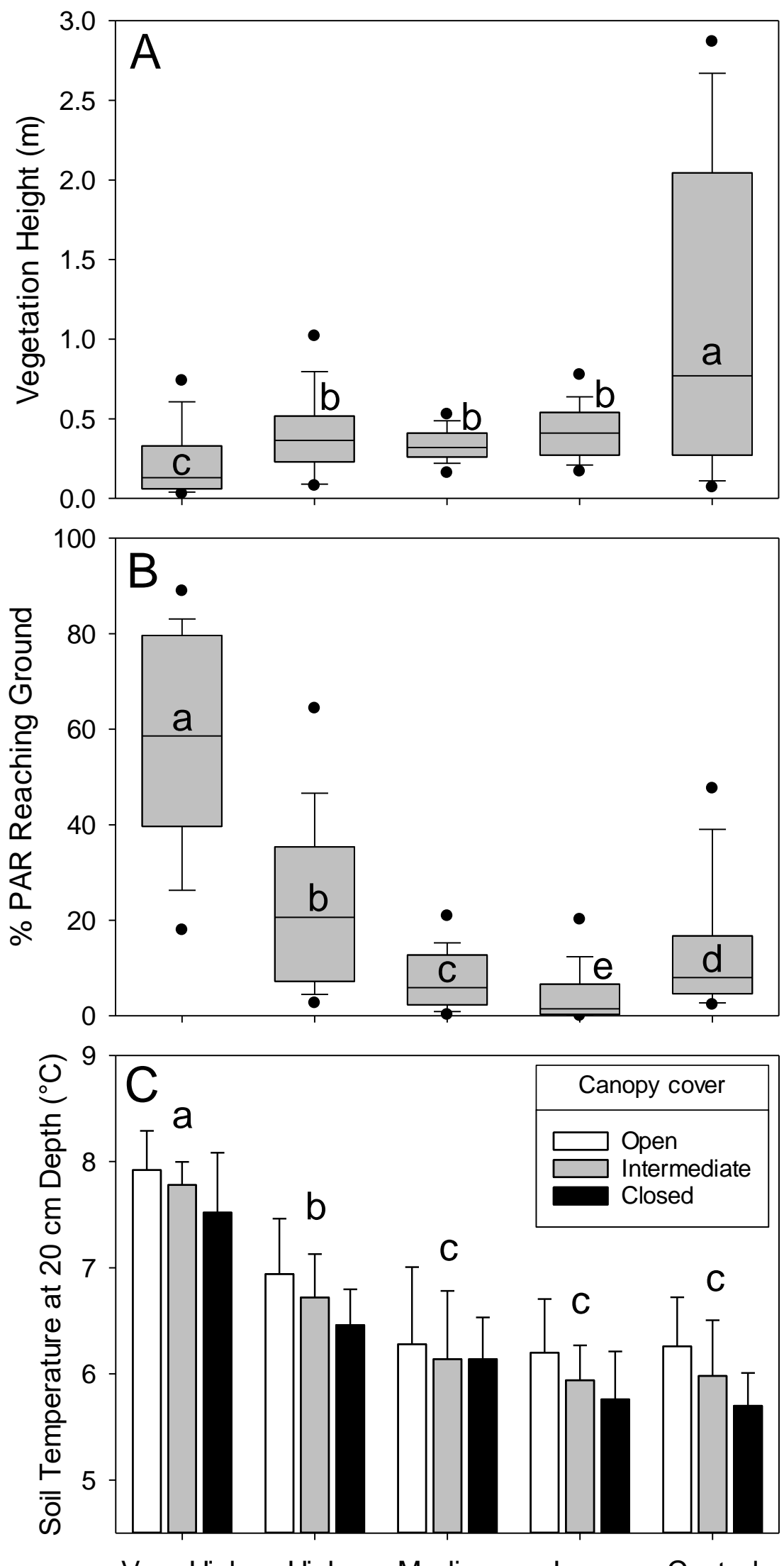

Fire Intensity 
bioRxiv preprint doi: https://doi.org/10.1101/2020.04.25.061051; this version posted April 27, 2020. The copyright holder for this preprint (which was not certified by peer review) is the author/funder, who has granted bioRxiv a license to display the preprint in perpetuity. It is made available under aCC-BY-NC-ND 4.0 International license.

$514 \quad$ Fig. 3

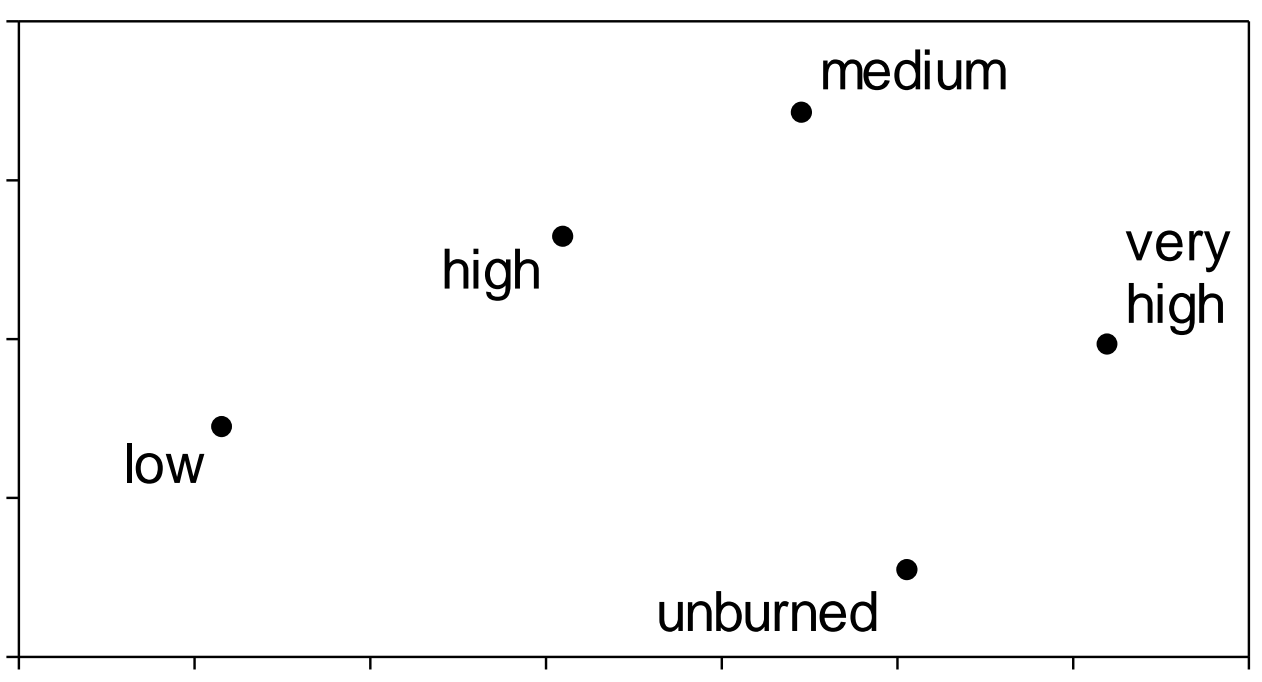

515

516 

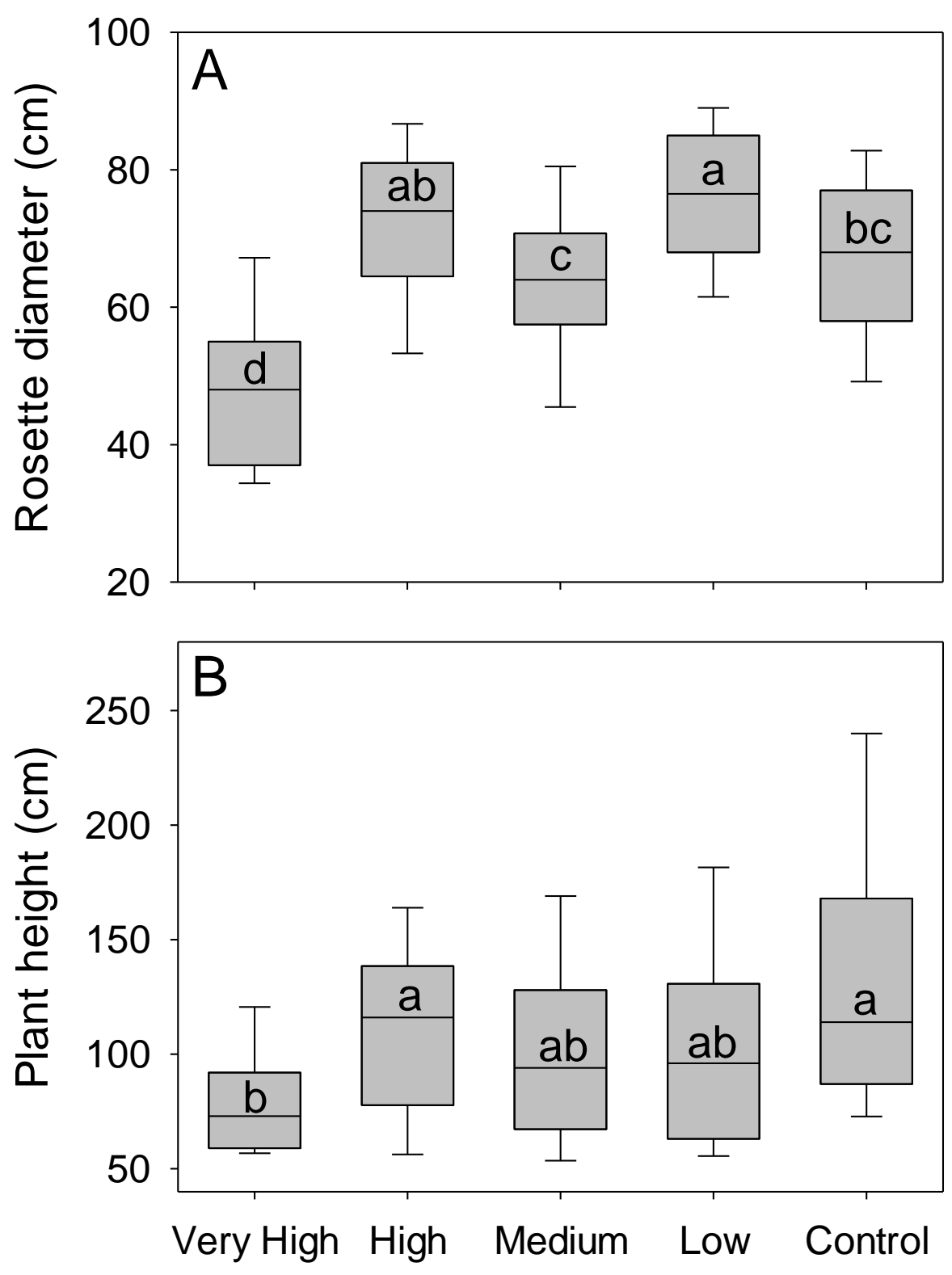
bioRxiv preprint doi: https://doi.org/10.1101/2020.04.25.061051; this version posted April 27, 2020. The copyright holder for this preprint (which was not certified by peer review) is the author/funder, who has granted bioRxiv a license to display the preprint in perpetuity. It is made available under aCC-BY-NC-ND 4.0 International license.

Fig. 5

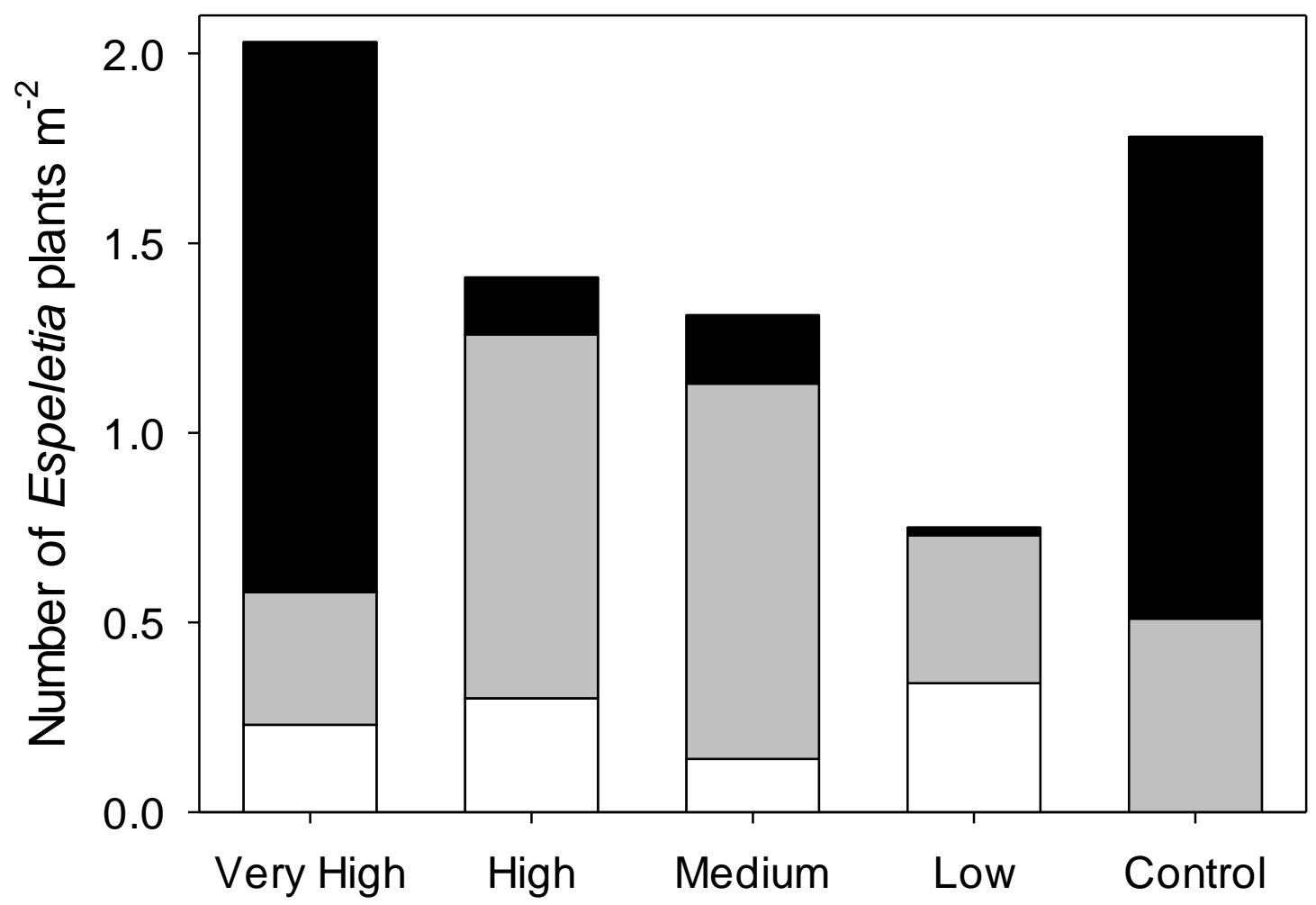

